\title{
PENGARUH PEMANFAATAN PERPUSTAKAAN SEKOLAH TERHADAP PRESTASI BELAJAR PESERTA DIDIK DI SMK PRATIDINA MAKASSAR
}

\author{
Saenal Abidin \\ Pengelola perpustakaan SMK Pratidina Makassar \\ Email: saenalnawang777@ gmail.com
}

\begin{abstract}
Abstrak: Teknik penarikan sampel dalam penelitian ini menggunakan teknik purposive sampling yakni dengan menentukan sampel dengan memilih peserta didik yang masuk penilaian sepuluh besar setiap kelas XII A, XII B, XII C, XII D. Instrumen yang digunakan dalam penelitian ini menggunakan nilai raport, pedoman observasi, angket, dan catatan dokumentasi. Analisis data yang digunakan adalah analisis regresi linier sederhana. Analisis pengembangan indikator dalam penelitian ini untuk mengetahui ada tidaknya pengaruh pemanfaatan perpustakaan terhadap prestasi belajar peserta didik SMK Pratidina Makassar, dikembangkan untuk mengetahui pemanfaatan perpustakaan berpengaruh positif atau tidak terhadap prestasi belajar peserta didik. Hasil penghitungan besarnya koefisien atau volume awal adalah sebesar 28,680 bernilai positif. Sedangkan untuk peningkatan setiap pemanfaatan perpustakaan diperoleh nilai konstanta sebesar 0,703. Nilai prestasi belajar peserta didik melalui penghitungan rumus regresi linier sederhana sebesar 29,138 tersebut menunjukkan bahwa semakin tinggi frekuensi pemanfaatan perpustakaan maka semakin tinggi peningkatan prestasi belajar peserta didik. Untuk mengetahui besarnya pengaruh pemanfaatan perpustakaan terhadap prestasi belajar, digunakan angka $\mathrm{R}$ square (angka korelasi yang dikuadratkan). Angka $\mathrm{R}$ square disebut juga Koefisien Diterminasi (KD) besarnya angka Koefisien Diterminasi dalam penghitungan di atas ialah sebesar 0,677 atau sama dengan 67,7\%. Angka tersebut mempunyai arti bahwa besarnya pengaruh pemanfaatan perpustakaan terhadap prestasi belajar sebesar $67,7 \%$ sedangkan sisanya, yaitu 32,3\% (100\%-67,7\%) di pengaruhi oleh variabel lain. Berdasarkan tabel interpretasi tingkat pengaruh yakni berada pada kategori cukup tinggi. Didasarkan pada hasil penghitungan diperoleh angka signifikansi sebesar 0,000. Angka 0,000 $<0,05$. Oleh karena itu, H0 ditolak dan H1 diterima. Artinya ada hubungan linier antara variabel pemanfaatan perpustakaan dengan prestasi belajar. Oleh karena terdapat hubungan linier antara kedua variabel maka frekuensi pemanfaatan perpustakaan memengaruhi prestasi belajar peserta didik di SMK Pratidina Makassar.
\end{abstract}

\section{Keywords: Pemanfaatan Perpustakaan, Prestasi Belajar.}

\section{PENDAHULUAN}

Salah satu prioritas pembangunan dibidang pendidikan yaitu dengan Pemanfaatan perpustakaan oleh peserta didik secara berkelanjutan serta erat kaitannya dengan proses pembelajaraan yang diselenggarakan oleh instansi pendidikan sekolah. Upaya penyelengaraan perpustakaan sekolah merupakan upaya untuk memelihara dan 
meningkatkan efisiensi dan efektivitas proses pembelajaran. Hal ini karena pola pembelajaran yang disebut sebagai keterbukaan informasi untuk memperoleh sebanyaksebanyaknya ilmu pengetahuan hanya akan terlaksana jika peserta didik dapat memanfaatkan perpustakaan, pendidik memberikan pelajaran hanya secara garis besarnya saja, sedangkan untuk mendetailnya peserta didik diminta untuk mempelajari buku-buku yang ada di perpustakaan dan kemudian mata pelajaran itu didiskusikan. Dengan sistem seperti ini, peserta didik harus memanfaatkan perpustakaan untuk mencari dan menelaah buku-buku yang ada di perpustakaan dalam proses belajarnya. Namun, ada juga dikalangan peserta didik yang tidak memanfaatkan perpustakaan dalam proses belajarnya karena merasa bahwa bahan pelajaran yang diberikan oleh guru sudah mencukupi. Selain itu, kurangnya tugas pengembangan bahan pelajaraan dan tugas mandiri dari pendidik menyebabkan peserta didik tidak termotivasi untuk pergi menelaah dan mencari bahan ke perpustakaan.

Perpustakaan merupakan pusat interaksi peserta didik dengan buku, sehingga perpustakaan dibutuhkan dalam proses pembelajaran. Kenyamanan dan kelengkapan koleksi adalah syarat mutlak untuk meningkatkan kemauan dan kemampuan belajar peserta didik. Sehingga, diperlukan pengelolaan perpustakaan yang serius mengenai penataan perpustakaan. Karena hal ini mempengaruhi minat peserta didik untuk belajar. Berbagai fasilitas dan layanan yang tersedia di perpustakaan termasuk bahan literatur, jurnal, karya tulis ilmiah dan majalah, hasil-hasil penelitian serta ada juga aktifitas kebudayaan. Pendidikan pada dasarnya usaha sadar untuk menumbuhkembangkan potensi sumber daya manusia peserta didik dengan cara mendorong dan menfasilitasi kegiatan belajar mereka.

Perpustakaan sekolah memegang peranan penting, seperti yang tertuang dalam Undang-undang Perpustakaan No. 43 tahun 2007 pasal 23 ayat 1 yang berbunyi: "setiap sekolah/madrasah wajib menyelenggarakan perpustakaan yang memiliki Standar Nasional Pendidikan".

Sekolah sebagai lembaga pendidikan yang melaksanakan kegiatan belajar dan pengajaran pendidikan dituntut untuk menghasilkan sumber daya manusia yang berkualitas. Untuk mencapai keberhasilan di sekolah, meliputi perlu didukung oleh seluruh komponen sekolah mencakup, antara lain kepala sekolah, tenaga kependidikan, pustakawan, peserta didik, kurikulum, metode pengajaran, serta berbagai fasilitas penunjang kegiatan belajar mengajar yang kedudukannya saling memengaruhi dan mendukung sebagai upaya pencapaian keberhasilan tujuan pendidikan. Untuk mencapai sebuah keberhasilan pendidikan, maka hal yang paling penting ialah ketersediaan fasilitas penunjang pendidikan yakni perpustakaan. Keberadaan ruang perpustakaan dalam sebuah instansi sekolah, dapat memberikan peluang yang lebih banyak bagi para peserta didik untuk berkreasi dan mengembangkan diri dengan memperbanyak kegiatan belajar mandiri diluar ruangan kelas yakni dengan banyak menyempatkan diri untuk membaca buku sebanyak-banyaknya demi memperluas wawasan berpikir dan tentunya akan berdampak bagi peningkatan prestasi belajar mereka.

Pemilihan peserta didik Sekolah Menengah Kejuruan Pratidina Makassar sebagai obyek penelitian didasarkan pada keinginan peneliti untuk mengetahui pengaruh pemanfaatan perpustakaan terhadap prestasi belajar peserta didik. Pemanfaatan perpustakaan khususnya di sekolah SMK Pratidina Makassar adalah hal yang wajib bagi setiap peserta didik kelas XII karena kebijakan kepala sekolah yang mengadakan jadwal khusus jam perpustakaan yang tertera pada roster mata pelajaran setiap harinya selama dua jam masing-masing kelas. Penambahan jam pustaka khusus 
diperuntukkan bagi kelas XII dikarenakan mereka akan mempersiapkan Ujian Nasional (UN) dan mengerjakan tugas akhir sebagai persyaratan mengikuti UN dengan menyelesaikan satu Karya Tulis Ilmiah (KTI) yang berhubungan dengan keperawatan sebagai sekolah kejuruan ilmu kesehatan. Adapun untuk peserta didik kelas X dan XI belum terdapat jadwal khusus pustaka tetapi mereka bisa memanfaatkan perpustakaan apabila ada jam kosong atau pada saat jam istirahat.

Setiap peserta didik yang masuk ke perpustakaan pada jam pustaka akan ditulis namanya dalam daftar hadir atau absensi khusus jam pustaka, sedangkan yang tidak masuk dinyatakan tidak mengikuti pembelajaran pustaka. Kehadiran peserta didik di perpustakaan ini akan menjadi referensi bagi para guru dengan melakukan konsultasi dengan pustakawan mengenai peserta didik dan akan menjadi nilai tambah dalam penilaian sikap sebagaimana teknik penilaian pada kurikulum 2013 yang mewajibkan adanya penilaian (SIKAP) pada laporan hasil belajar peserta didik. Kurikulum 2013 diberlakukan pemerintah bagi sekolah yang sanggup untuk merealisasikannya.

Kebijakan pengadaan jam pustaka dilakukan oleh pihak sekolah untuk memberikan durasi yang lebih panjang untuk belajar mandiri bagi peserta didik di sekolah dalam mengerjakan tugas sekolah, mengerjakan Karya Tulis Ilmiah atau sekedar mencari referensi sebagai bahan diskusi di kelas. Fakta empiris yang ditemukan peneliti saat melakukan observasi awal yakni masih adanya peserta didik yang kurang memahami pentingnya perpustakaan terhadap prestasi belajarnya, akibatnya mereka malas memanfaatkan perpustakaan walaupun jam pustaka berlangsung, bahkan ada yang mengaku bahwa jam pustaka yang diberlakukan disekolah tidak berpengaruh terhadap prestasi belajarnya. Atas dasar latar belakang tersebut, peneliti tertarik untuk melakukan penelitian atas fenomena yang terjadi tentang bagaimana pengaruh pemanfaatan perpustakaan sekolah terhadap prestasi belajar peserta didik kelas XII angkatan VI SMK Pratidina Makassar”.

\section{TINJAUAN PUSTAKA}

\section{A. Perpustakaan Sekolah}

Menuntut ilmu merupakan kewajiban bagi setiap manusia dengan berbagai cara dan tindakan yang dilakukan demi memperoleh ilmu pengetahuan, Salah satunya dengan cara mengikuti lembaga pendidikan formal (sekolah) dimana sekolah merupakan wadah seseorang memperoleh ilmu pengetahuan. Ilmu pengetahuan dapat diperoleh jika seseorang gemar belajar dan menuntut ilmu.

\section{1) Pengertian Perpustakaan Sekolah}

Dalam Kamus Besar Bahasa Indonesia, kata perpustakaan berasal dari kata pustaka, yang berarti: “(1) kitab, buku-buku, (2) kitab primbon. Kemudian kata pustaka mendapat awalan per dan akhiran an, menjadi perpustakaan. Perpustakaan mengandung arti: (1) kumpulan buku-buku bacaan, (2) bibliotek, dan (3) buku-buku kesusastraan,"1 Selanjutnya ada pula istilah pustakaloka yang berarti tempat atau ruangan perpustakaan.

Menurut Bafadal, Perpustakaan adalah "suatu unit kerja dari suatu badan atau lembaga tertentu yang mengelola bahan-bahan pustaka, baik berupa buku-buku maupun bukan berupa buku yang diatur secara sistematis menurut aturan tertentu sehingga dapat digunakan sebagai sumber informasi oleh setiap pemakainya". ${ }^{2}$

\footnotetext{
${ }^{1}$ Departemen Pendidikan Nasional, Kamus Besar Bahasa Indonesia: Cetakan Keempat. Jakarta: Balai Pustaka. h. 1093.

${ }^{2}$ Ibrahim Bafadal. Pengelolaan Perpustakaan Sekolah. Jakarta: Bumi Aksara. h. 20
} 
Dari Pengertian di atas, dapat diketahui bahwa perpustakaan yaitu mencakup suatu ruangan, bagian dari gedung/bangunan, atau gedung tersendiri, yang berisi buku-buku koleksi, yang disusun dan diatur sedemikian rupa, sehingga mudah untuk dicari dan dipergunakan apabila sewaktu-waktu diperlukan oleh pembaca. Perpustakaan dilengkapi dengan berbagai sarana prasarana, seperti ruangan baca, rak buku, rak majalah, meja kursi baca kartu-kartu katalog, sistem pengelolaan tertentu, dan ditempatkan karyawan atau petugas yang melaksanakan kegiatan perpustakaan agar semuanya berjalan sebagaimana mestinya.

\section{2) Standar Perpustakaan Sekolah}

Pemerintah Indonesia melalui Undang-undang nomor, 43 Tahun 2007 tentang perpustakaan yang kemudian secara eksplisit diatur melalui peraturan Pemerintahan bab III pasal 11 tahun 2007 tentang Standar Nasional Perpustakaan, di sebutkan bahwa:

Standar Nasional Perpustakaan terdiri atas:
(a) Standar koleksi
(b) Standar sarana dan prasarana
(c) Standar pelayanan perpustakaan
(d) Standar tenaga perpustakaan
(e) Standar penyelenggaraan
(f) Standar pengelolaan. ${ }^{3}$

\section{B. Prestasi Belajar}

\section{1) Pengertian Prestasi Belajar}

Dalam pengertian yang umum atau lebih popular, belajar adalah mengumpulkan sejumlah pengetahuan. Pengetahuan tersebut diperoleh dari seseorang yang lebih tahu atau sekarang ini dikenal dengan guru, dalam belajar pengetahuan tersebut dikumpulkan sedikit demi sedikit hingga akhirnya menjadi banyak. Orang yang banyak pengetahuannya diidentifikasi sebagai orang yang banyak belajar, sementara orang yang sedikit pengetahuannya diidentifikasi sebagai orang yang sedikit belajar, dan orang yang tidak berpengetahuan dipandang sebagai orang yang tidak belajar.

Adapun tujuan inti dalam proses belajar mengajar adalah untuk mengetahui sejauh mana kemajuan peserta didik. Oleh karena itu, evaluasi sangat penting. Evaluasi dapat diartikan "penilaian terhadap tingkat keberhasilan siswa mencapai tujuan yang telah ditetapkan dalam sebuah program". " Jadi fungsi dari evaluasi adalah agar guru dapat mengetahui sampai sejauh mana kemampuan para peserta didik dalam menerima ilmu pengetahuan yang disampaikan oleh guru.

Dalam pelaksanaan pendidikan di sekolah, proses kegiatan belajar dan mengajar merupakan suatu kegiatan yang paling pokok, karena berhasil tidaknya pencapaian tujuan pendidikan tergantung pada proses belajar mengajar yang dialami oleh peserta didik. Oleh karena itu, prestasi erat kaitanya dengan belajar.

\footnotetext{
${ }^{3}$ Undang-Undang Republik Indonesia nomor, 43 tahun 2007 tentang Perpustakaan, (Jakarta:Perpustakaan Nasional), h. 8-9.

${ }^{4}$ Muhibbin Syah, Pisikologi Pendidikan dengan Pendekataan Baru, (Cet 15; Bandung: PT Remaja Rosdakarya, 2010). h. 139.
} 


\section{2) Upaya Meningkatkan Prestasi Belajar}

Prestasi belajar peserta didik merupakan kelanjutan dari pembahasan tentang faktor-faktor yang mempengaruhi prestasi belajar peserta didik. Karena keberhasilan belajar peserta didik sangat tergantung pada bagaimana keadaan atau kondisi faktorfaktor itu meliputi dirinya. Apakah faktor-faktor itu berada pada kondisi yang positif (cukup, baik atau tepat) ataukah dalam kondisi yang negatif. Menurut mulyana, dalam upaya meningkatkan prestasi belajar, "keadaan jasmani, keadaan sosial emosional, lingkungan, memulai pelajaran, membagi pekerjaan, control, sikap optimis, mengunakan waktu, cara mempelajari buku, dan mempertinggi kecepatan membaca peserta didik". 5 Kondisi faktor-faktor yang mempengaruhi prestasi belajar yang baik, diperlukan jasmani yang sehat, dalam keadaan jasmani yang sehat apabila jasmani dalam keadaan sakit, kurang gizi, kurang istirahat maka tidak dapat belajar dengan efektif. Keadaan sosial emosional, peserta didik yang mengalami kegoncangan emosi yang kuat, atau mendapat tekanan jiwa, demikian pula anak yang tidak disuka temanya tidak dapat belajar secara efektif, karena kondisi ini sangat mempengaruhi konsentrasi pikiran, kemauan dan perasaan.

Kondisi positif, baik faktor internal, eksternal maupun faktor pendekatan belajar maka seorang peserta didik dapat dipastikan akan memperoleh keberhasilan dalam belajarnya dan menjadi siswa yang berprestasi tinggi. Sebaliknya jika faktorfaktor tersebut dalam kondisi yang negatif didapati oleh siswa maka dapat dipastikan siswa tersebut akan menemui banyak masalah dalam belajarnya dan tidak akan memperoleh keberhasilan yang baik dalam belajarnya.

\section{METODOLOGI PENELITIAN}

Jenis penelitian adalah penelitian kuantitatif dengan pendekatan positivistik dan pedagogis pada lokasi SMK Pratidina Makassar. populasi dalam penelitian ini adalah sebanyak 216 orang peserta didik kelas XII SMK Pratidina Makassar angkatan ke-VI. Sampel dalam penelitian ini adalah peserta didik yang rajin memanfaatkan perpustakaan dengan melihat frekuensi pemanfaatan perpustakaan berdasarkan data dan informasi yang ada di perpustakaan SMK Pratidina Makassar. Frekuensi pemanfaatan perpustakaan dapat dilihat pada daftar kunjungan tertinggi dan peminjaman koleksi terbanyak yang terdaftar secara sistematis pada program Senayan Library Management Sistem (SLIMS) yang ada di perpustakaan. Penelitian Lapangan (filed research) yaitu mengadakan kegiatan menghimpun data di lapangan dengan menggunakan alat pengumpul data seperti: a) observasi; b) angket/kuesioner, dan c) dokumentasi.

Agar data yang dikumpulkan baik dan benar, instrumen pengumpulan datanya pun harus baik. Adapun instrument pengumpulan data yaitu dengan pedoman observasi, dan angket sebagai instrumen penelitian agar dapat menuntun penulis sekaligus dapat memperoleh informasi dari sumber data dengan menggunakan skala likert.

Adapun teknik yang digunakan dalam pengolahan data adalah metode kuantitatif yakni data yang diperoleh dalam penelitian ini diolah secara deskriptif, kritis, dan interpretatif dengan menggunakan analisis bersifat angka-angka yang menunjukkan jumlah persentase dan frekuensi, sehingga harus dianalisis secara kuantitatif. Data yang diperoleh selanjutnya dianalisis menggunakan duan teknik analisis yaitu: analisis deskriptif kuantitatif dan analisis statistik inferensial. Analisis deskriptif adalah analisis

${ }^{5}$ Mulyasa, Implemntasi Kurikulum 2004 Panduan Pembelajaran KBK, (Cet IV; Bandung: PT Remaja Rosdakarya, 2006), h. 195. 
yang berfungsi untuk mendeskriptifkan atau memberi gambaran terhadap objek yang diteliti melalui data dan sampel dan sampel atau populasi sebagaimana adanya tanpa melakukan analisis dari kesimpulan yang berlaku umum. Sedangkan analisis statistik inferensial berfungsi untuk mengelompokkan data, menggarap, menyimpulkan, memaparkan serta menyajikan hasil laporan.

Untuk mengetahui sumbangan pengaruh variabel X terhadap Y dapat ditentukan dengan rumus korelasi determinan. Koefisien determinasi adalah kuadrat dari koefisien korelasi yang dikalikan dengan $100 \%$. Untuk mengetahui seberapa besar variabel $\mathrm{X}$ mempunyai sumbangan atau ikut menentukan variabel $\mathrm{Y}$, dapat dicari dengan rumus:

$K D=r^{2} \times 100 \%$

Keterangan $: \mathrm{KD}=$ Nilai Koefisien diterminan (kontribusi antara variabel) $\mathrm{r}=$ Nilai koefisien korelasi.

Berdasarkan Rumus tersebut, untuk mengetahui pengaruh pemanfaatan perpustakaan ditentukan oleh nilai koefisien determinasi. Hal tersebut diketahui berapa besar pengaruh pemanfaatan perpustakaan terhadap prestasi belajar sehingga diketahui tingkat signifikansinya, apakah dalam kategori sangat tinggi, tinggi, sedang, rendah dan sangat rendah. Kategori hasil penelitian dapat terlihat pada tabel berikut: ${ }^{6}$

Tabel III.1

Pedoman Pemberian Interpretasi Tingkat Pengaruh

\begin{tabular}{|c|c|}
\hline Interval Koefisien & Tingkat Pengaruh \\
\hline $90-100$ & Sangat Tinggi \\
\hline $70-89$ & Tinggi \\
\hline $50-69$ & Cukup tinggi \\
\hline $20-49$ & Rendah \\
\hline $10-19$ & Sangat rendah \\
\hline
\end{tabular}

\section{HASIL PENELITIAN DAN PEMBAHASAN}

\section{Hasil Penelitian}

a. Kondisi Obyektif Pemanfaatan Perpustakaan SMK Pratidina Makassar

Perpustakaan SMK Pratidina menempati sebuah ruangan seluas $\pm 50^{2}$ dengan lebar 5 meter dan panjang ruangan sekitar 10 meter. Perpustakaan SMK Pratidina terletak di sebelah barat lokasi sekolah berdampingan dengan ruangan BK (Bimbingan Konseling). Letaknya terbilang kurang strategis sebab tidak berdampingan langsung dengan ruangan kelas tempat belajar peserta didik.

Perpustakaan SMK Pratidina Makassar memiliki beberapa fasilitas penunjang proses pembelajaran, diantaranya buku paket penunjang kurikulum 2013, buku fiksi dan non-fiksi, buku kesehatan, referensi, kamus, ensiklopedi, Karya Tulis Ilmiah, CD-R file KTI alumni, majallah, arsip UN/UAS/Soal-soal Ujian harian, arsip Praktik Belajar Lapangan dan lain-lain.

1) Persepsi peserta didik terhadap pentingnya memanfaatkan perpustakaan sekolah.

Dalam penelitian ini, salah satu indikator yang digunakan adalah persepsi peserta didik. Apabila persepsi peserta didik berada pada kategori baik atau sangat baik, maka hal ini tentu akan berdampak pada semangat mereka dalam memanfaatkan perpustakaan sebagai sumber belajar di sekolah. Sebaliknya, jika persepsi mereka berada pada kategori cukup atau kurang baik dalam arti menganggap bahwa perpustakaan tidak terlalu penting dalam menunjang kegiatan belajar mereka, maka

${ }^{6}$ Suharsimi Arikunto, Prosedur Penelitian: Suatu Pendekatan Praktik (Ed. Rev., cet.1) h. 284 
frekuensi berkunjung dan semangat belajar mereka di perpustakaan tentu akan berkurang dan fungsi perpustakaan yang sesungguhnya sebagai sumber belajar sepanjang hayat akan terbaikan. Olehnya itu, persepsi dan semangat belajar mereka di perpustakaan sebaiknya terus ditingkatkan agar dapat meningkatkan prestasi belajar mereka. Frekuensi dan persentase persepsi peserta didik terhadap pentingnya perpustakaan sekolah dapat dilihat dalam tabel di bawah ini:

Tabel 1

Tabel Frekuensi Hasil Angket Indikator Persepsi Peserta Didik Terhadap Pentingnya Memanfaatkan Perpustakaan Sekolah

\begin{tabular}{|c|c|c|c|c|}
\hline I & Alternatif Jawaban & Skor & Frekuensi (f) & Persentase \% \\
\cline { 2 - 5 } N & Sangat Baik & 5 & 236 & $59 \%$ \\
\cline { 2 - 5 } D & Baik & 4 & 127 & $31,8 \%$ \\
\cline { 2 - 5 } I & Ragu-ragu & 3 & 37 & $9,2 \%$ \\
\cline { 2 - 5 } K & Kurang & 1 & 0 & 0 \\
\cline { 2 - 5 } T & Tidak Baik & $\mathbf{4 0 0}$ & $\mathbf{1 0 0 \%}$ \\
\cline { 2 - 5 } O & Jumlah & & \\
\hline
\end{tabular}

Data pada tabel 1 di atas, menggambarkan jawaban responden secara keseluruhan pada indikator persepsi yakni sebesar 59\% peserta didik memiliki persepsi yang sangat baik terhadap perpustakaan atau menganggap perpustakaan adalah fasilitas belajar yang sangat penting dalam institusi pendidikan. Begitu pula dengan peserta didik yang menyatakan baik sebesar $31,8 \%$. Hal ini menandakan bahwa persepsi peserta didik SMK Pratidina Makassar terhadap perpustakaan sekolah berada pada kategori sangat baik dalam memanfaatkan perpustakaan di sekolah. Meskipun masih ada sebesar 9,2\% peserta didik yang masih ragu-ragu tentang pentingnya perpustakaan namun hal itu dapat dimaklumi sebab tidak semua peserta didik memiliki minat baca yang tinggi namun bukan berarti mereka tidak pernah memanfaatkan perpustakaan sekolah.

2) Motivasi peserta didik dalam memanfaatkan perpustakaan

Dalam penelitian ini, indikator kedua yang digunakan adalah motivasi peserta didik. Apabila motivasi peserta didik berada pada kategori baik, tentu berdampak pada semangat mereka dalam memanfaatkan perpustakaan sebagai sumber belajar di sekolah. Sebaliknya, jika motivasi mereka kurang baik, maka frekuensi dalam berkunjung ke perpustakaan tentunya akan kurang. Olehnya itu, selain persepsi yang baik perlu ditanamkan, motivasi dan semangat belajar mereka di perpustakaan sebaiknya terus dibina dan ditingkatkan. Frekuensi dan persentase motivasi peserta didik dalam memanfaatkan perpustakaan sekolah dapat dilihat dalam tabel di bawah ini:

\section{Tabel 2}

Tabel Frekuensi Hasil Angket Indikator Motivasi Peserta Didik Dalam Memanfaatkan Perpustakaan Sekolah

\begin{tabular}{|c|c|c|c|c|}
\hline I & Alternatif Jawaban & Skor & Frekuensi (f) & Persentase \% \\
\cline { 2 - 5 } N & Sangat Baik & 5 & 233 & $\mathbf{5 8 , 2 \%}$ \\
\cline { 2 - 5 } D & Baik & 4 & 96 & $\mathbf{2 4 \%}$ \\
\cline { 2 - 5 } I & Ragu-ragu & 3 & 60 & $\mathbf{1 5 \%}$ \\
\cline { 2 - 5 } K & Kurang & 2 & 11 & $\mathbf{2 , 8 \%}$ \\
\cline { 2 - 5 } T & Tidak Baik & 1 & 0 & $\mathbf{0}$ \\
\cline { 2 - 5 } O & & $\mathbf{4 0 0}$ & $\mathbf{1 0 0 \%}$ \\
R & Jumlah & & & \\
\hline
\end{tabular}


Data pada tabel 2 di atas, menggambarkan jawaban responden secara keseluruhan pada indikator motivasi yakni sebesar 58,2\% menjawab Sangat baik dan $24 \%$ menjawab baik. Sedangkan yang menjawab masih ragu-ragu sebesar $15 \%$ dan 2,8\% mengaku belum memiliki motivasi yang kuat untuk memanfaatkan perpustakaan. Hal ini berbeda dengan indikator persepsi yang tidak satupun peserta didik merasa memiliki persepsi yang kurang baik terhadap perpustakaan, yang ada hanya merasa ragu-ragu.

Adapun motivasi belajar peserta didik SMK Pratidina Makassar di perpustakaan berdasarkan tabel 2 di atas berada pada kategori sangat baik. Karena rata-rata peserta didik menjawab mengaku motivasinya sangat baik. Walaupun dalam indikator motivasi, terdapat $2,8 \%$ mengaku kurang termotivasi untuk berkunjung ke perpustakaan. Hal ini dapat disimpulkan bahwa apabila persepsi peserta didik baik terhadap perpustakaan, belum tentu mereka memiliki motivasi yang kuat dalam memanfaatkan perpustakaan. Penyebab dari masalah ini dapat kita identifikasi dari beberapa pernyataan yang dimuat dalam indikator motivasi, diantaranya adalah peserta didik merasa bahwa perpustakaan kurang berpengaruh terhadap prestasi belajar mereka, walaupun mereka menganggap bahwa perpustakaan adalah tempat belajar yang menyediakan berbagai literatur penting dalam pembelajaran, namun mereka kurang termotivasi untuk berkunjung ke perpustakaan. Pandangan seperti ini terjadi pada peserta didik yang kurang memiliki minat membaca atau kurang menyadari bahwa dengan banyak membaca buku dapat memperluas wawasan dan referensi belajar yang nantinya dapat dijadikan sebagai bahan diskusi di kelas yang tentunya secara tidak langsung akan berpengaruh terhadap prestasi belajar mereka.

3) Rekapitulasi Hasil Angket Pemanfaatan Perpustakaan

Rekapitulasi data penelitian secara keseluruhan apabila digabungkan dapat dilihat pada tabel frekuensi berikut ini:

Tabel 3

Rekapitulasi Hasil Angket Pemanfaatan Perpustakaan SMK Pratidina Makassar

\begin{tabular}{|c|c|c|c|c|}
\hline No & Alternatif Jawaban & $\begin{array}{c}\text { Skor } \\
\text { Pernyataan }\end{array}$ & Frekuensi (f) & $\begin{array}{c}\text { Persentase } \\
(\%)\end{array}$ \\
\hline 1 & Sangat Baik & 5 & 475 & $59,4 \%$ \\
\hline 2 & Baik & 4 & 220 & $27,5 \%$ \\
\hline 3 & Ragu-ragu & 3 & 94 & $11,7 \%$ \\
\hline 4 & Kurang & 2 & 11 & $1,4 \%$ \\
\hline 5 & Tidak Baik & 1 & $\mathbf{0}$ & $0 \%$ \\
\hline \multicolumn{3}{|c|}{ Jumlah } & 800 & $100 \%$ \\
\hline
\end{tabular}

Data pada tabel 3 di atas menunjukkan tingkat pemanfaatan perpustakaan secara deskriptif dan menggambarkan jawaban responden terhadap angket pemanfaatan perpustakaan SMK Pratidina Makassar. Jawaban sangat baik sebesar $59,3 \%$, menyatakan baik sebesar 27,5\%, jawaban ragu-ragu sebesar $11,7 \%$, dan jawaban pernyataan kurang baik sebesar $1,4 \%$. Asumsi dari data tersebut di atas bahwa pemanfaatan perpustakaan SMK Pratidina Makassar yang ditunjukkan melalui indikator-indikator yang terdapat pada angket berada pada kategori sangat baik dalam memanfaatkan perpustakaan. Kategori sangat baik dibuktikan dengan jawaban responden yang menjawab sangat baik dan baik jauh lebih banyak jika 
dibandingkan dengan yang menjawab kurang baik. Data tersebut menggambarkan secara umum peserta didik SMK Pratidina Makassar secara rata-rata memiliki persepsi dan motivasi yang sangat baik terhadap perpustakaan dan selalu memanfaatkan perpustakaan dalam pembelajaran setiap hari di sekolah demi mendongkrak peningkatan prestasi belajar mereka.

SMK Pratidina Makassar merupakan sekolah keperawatan dengan akreditasi A dengan predikat Amat Baik oleh Badan Akreditasi Nasional BAN S/M mewajibkan adanya jam khusus perpustakaan minimal dua jam perhari yang tertera dalam jadwal mata pelajaran. Olehnya itu, kesempatan untuk belajar mandiri peserta didik di perpustakaan menjadi lebih banyak. Hal inilah yang perlu diperhatikan agar minimal dua jam perhari tersebut dapat dimaksimalkan dan tujuan perpustakaan dapat tercapai. Untuk mencapai fungsi perpustakaan yang baik, tentunya harus meningkatkan persepsi yang baik terhadap perpustakaan, hal itu dapat dilakukan dengan mengembangkan perpustakaan dari berbagai hal dengan memperhatikan Standar Nasional Perpustakaan (SNP) yang tertera dalam Undang-Undang Republik Indonesia No. 43 tahun 2007 tentang perpustakaan, yakni memperhatikan standar koleksi, standar sarana dan prasarana, standar tenaga perpustakaan, standar penyelenggaraan, dan standar pengelolaan. ${ }^{7}$

Perpustakaan ideal adalah perpustakaan yang mengikuti Standar nasional Pendidikan (SNP). Berdasarkan observasi dan hasil penelitian ini, peneliti menyimpulkan bahwa perpustakaan SMK Pratidina Makassar secara umum telah memenuhi kriteria yang tertera dalam Standar Nasional Pendidikan (SNP) yakni koleksi yang ada cukup memadai dari berbagai disiplin ilmu dan terdiri dari 14.118 eksamplar koleksi dengan beragam judul, sarana dan prasarana cukup memadai, latar belakang tenaga perpustakaan dari strata satu (S1) Ilmu Perpustakaan, penyelenggaraan dan pengelolaan berdasarkan aturan baku. Hal yang masih perlu ditingkatkan adalah pembinaan minat baca peserta didik, pembinaan persepsi dan motivasi belajar di perpustakaan agar semakin ditingkatkan serta perluasan ruang perpustakaan agar dapat menampung lebih banyak peserta didik yang ingin belajar di perpustakaan.

\section{b. Pemanfaatan Perpustakaan dan Pengaruhnya Terhadap Peningkatan Prestasi Belajar Peserta Didik di SMK Pratidina Makassar}

Analisis pengembangan indikator dalam penelitian ini untuk mengetahui seberapa besar pengaruh pemanfaatan perpustakaan terhadap prestasi belajar peserta didik SMK Pratidina Makassar. Indikator yang dikembangkan untuk mengetahui pemanfaatan perpustakaan oleh peserta didik ialah persepsi dan motivasi melalui angket yang disampaikan kepada peserta didik kelas XII angk.VI SMK Pratidina Makassar. Sedangkan indikator yang dikembangkan untuk mengetahui prestasi belajar adalah nilai yang diperoleh peserta didik yang tercantum di dalam laporan hasil belajar semester genap kelas XII angk.VI SMK Pratidina Makassar. Nilai-nilai yang diperoleh kemudian diolah menggunakan software IBM SPSS Statistics 21. Langkah selanjutnya menghitung data tersebut untuk mengetahui seberapa besar pengaruh pemanfaatan perpustakaan terhadap prestasi belajar peserta didik SMK Pratidina Makassar dengan menggunakan rumus regresi linier sederhana.

\footnotetext{
${ }^{7}$ Undang-Undang Republik Indonesia nomor, 43 tahun 2007 tentang Perpustakaan, h. 8-9.
} 
Untuk mengetahui prediksi peningkatan prestasi belajar setiap pemanfaatan perpustakaan dapat dilihat pada tabel berikut:

Tabel 8

Analisis Regresi

\begin{tabular}{|c|c|c|c|c|c|c|}
\hline \multirow{2}{*}{\multicolumn{2}{|c|}{ Model }} & \multicolumn{2}{|c|}{$\begin{array}{l}\text { Koefisien tidak } \\
\text { distandarisasi }\end{array}$} & \multirow{2}{*}{$\begin{array}{c}\text { Koefisien yang } \\
\text { distandarisasi }\end{array}$} & \multirow[b]{2}{*}{$\mathrm{T}$} & \multirow[b]{2}{*}{ Sig. } \\
\hline & & B & \begin{tabular}{|c|} 
Std. \\
Kesalaha \\
$\mathrm{n}$
\end{tabular} & & & \\
\hline \multirow[t]{2}{*}{1} & $\begin{array}{l}\text { (Constant/volume } \\
\text { awal) }\end{array}$ & 28.680 & 6.859 & & 4.181 & .000 \\
\hline & $\begin{array}{l}\text { Nilai rasio untuk } \\
\text { setiap Pemanfaatan } \\
\text { Perpustakaan }\end{array}$ & .703 & .079 & .823 & 8.919 & .000 \\
\hline
\end{tabular}

(Sumber: Hasil analisis data SPSS)

\section{Persamaan regresinya sebagai berikut:}

$$
\begin{array}{ll}
\mathrm{Y} & =\mathrm{a}+\mathrm{bX} \\
\mathrm{Y} & =28,680+0,703 \mathrm{X}
\end{array}
$$

Dari tabel 8 di atas terlihat bahwa nilai Variabel dependen (Y) sebesar 28,680 (volume awal) apabila koefisien variabel independen (X) sama dengan nol, menandakan bahwa nilai yang diperoleh peserta didik jika tidak memanfaatkan perpustakaan adalah sebesar 28,7. Koefisisen regresi variabel (X) sebesar 0,703 merupakan nilai rasio untuk setiap peningkatan nilai variabel $X$ artinya bahwa jika pemanfaatan perpustakaan mengalami peningkatan sebesar satu nilai maka prestasi belajar (Y) akan mengalami perubahan sebesar 0,703. Perubahan ini menggambarkan hubungan variabel dependen dan independen ke arah yang positif dan negatif.

Jika koefisien (b) bernilai positif, maka akan menunjukkan hubungan yang positif antara variabel dependen dan independen begitupula sebaliknya. Dari hasil analisis regresi linier sederhana diperoleh nilai $b=0,703$ (bernilai positif). Hal ini berarti:

1. Setiap kali nilai variabel $X$ atau pemanfaatan perpustakaan mengalami peningkatan, maka nilai variabel $\mathrm{Y}$ atau prestasi belajar peserta didik meningkat sebesar 0,703 (nilai konstanta) dari nilai Variabel X.

2. Besaran nilai variabel dependen (Y) sama dengan volume awal (konstanta) di tambah dengan peningkatan 0,703 dari nilai variabel independen $(\mathrm{X})$.

3. Bila variabel $\mathrm{X}$ (pemanfaatan perpustakaan) diketahui, maka nilai variabel $\mathrm{Y}$ atau peningkatan prestasi belajar dapat diperkirakan dengan cara memasukkan nilai tersebut ke dalam persamaan berikut:

$$
\begin{aligned}
& Y=28,680+0,703 x \\
& Y=29,383
\end{aligned}
$$

Nilai prestasi belajar peserta didik sebesar 29,138 tersebut menunjukkan bahwa semakin tinggi frekuensi pemanfaatan perpustakaan maka semakin tinggi peningkatan prestasi belajar peserta didik. Konstanta regresi linier sederhana menunjukkan bahwa bahwa setiap pemanfaatan perpustakaan akan meningkatkan prestasi belajar peserta didik SMK Pratidina Makassar sebesar 0,703. 
Untuk melihat tingkat pengaruh pemanfaatan perpustakaan dapat dilihat pada tabel berikut dengan melihat nilai $R$-Square:

\section{Tabel 9}

Hasil Penghitungan Pengaruh Pemanfaatan perpustakaan Terhadap Prestasi Belajar Peserta Didik

\begin{tabular}{|l|l|l|l|c|}
\hline \multicolumn{5}{|c|}{ Model Summary $^{\text {B }}$} \\
\hline $\begin{array}{l}\text { Mode } \\
1\end{array}$ & $\mathrm{R}$ & $R$ Square & yang disesuaikan $R$ Square & $\begin{array}{c}\text { Std. Kesalahan } \\
\text { perkiraan }\end{array}$ \\
\hline 1 & $.823^{\mathrm{a}}$ & .677 & .668 & 1.15743 \\
\hline
\end{tabular}

(Sumber: Hasil analisis data SPSS)

Untuk mengetahui besarnya pengaruh pemanfaatan perpustakaan terhadap prestasi belajar, digunakan angka $\mathrm{R}$ square (angka korelasi yang dikuadratkan). Angka $\mathrm{R}$ square disebut juga Koefisien Diterminasi (KD) besarnya angka Koefisien Diterminasi dalam penghitungan di atas ialah sebesar 0,677 atau sama dengan 67,7\% Rumus untuk menghitung Koefisien Ditermenasi adalah:

$K D=r^{2} \times 100 \%$

Angka tersebut mempunyai arti bahwa besarnya pengaruh pemanfaatan perpustakaan terhadap prestasi belajar sebesar $67,7 \%$ sedangkan sisanya, yaitu $32,3 \%$ (100\%-67,7\%) dipengaruhi oleh variabel lain. Jika dikonsultasikan dengan tabel interpretasi tingkat pengaruh menurut sugiyono, ${ }^{8}$ maka berada pada kategori cukup tinggi. Kategori tersebut dapat dilihat pada tabel berikut:

\section{Tabel 10}

Pedoman Interpretasi Tingkat Pengaruh

\begin{tabular}{|c|c|}
\hline Interval Koefisien & Tingkat Pengaruh \\
\hline $90-100$ & Sangat Tinggi \\
\hline $70-89$ & Tinggi \\
\hline $50-69$ & Cukup tinggi \\
\hline $20-49$ & Rendah \\
\hline $10-19$ & Sangat rendah \\
\hline
\end{tabular}

\section{Uji Hubungan Linieritas:}

Kemudian untuk menguji regresi tersebut di atas, maka perlu dilakukan pengujian hubungan linieritas antara variabel frekuensi pemanfaatan perpustakaan dengan prestasi belajar maka angka yang digunakan ialah seperti terdapat pada tabel hasil penghitungan berikut:

\footnotetext{
${ }^{8}$ Suharsimi Arikunto, Prosedur Penelitian: Suatu Pendekatan Praktik. h. 284
} 
Tabel 11

Hasil Penghitingan Uji Hubungan Linieritas Antara Variabel Independen dan Dependen

\begin{tabular}{|c|c|c|c|c|c|c|}
\hline \multicolumn{7}{|c|}{ ANOVA $^{b}$} \\
\hline \multicolumn{2}{|c|}{ Model } & Sum of Squares & Df & Mean Square & $\mathrm{F}$ & Sig. \\
\hline \multirow{3}{*}{1} & Pengurangan & 106.560 & 1 & 106.560 & 79.544 & $.000^{\mathrm{a}}$ \\
\hline & Sisa & 50.906 & 38 & 1.340 & & \\
\hline & Total & 157.466 & 39 & & & \\
\hline \multicolumn{7}{|c|}{ a. Prediksi: (Constant/tetap), PEMANFAATAN_PERPUSTAKAAN } \\
\hline \multicolumn{7}{|c|}{ b. Variabel dependen: PRESTASI_SISWA } \\
\hline
\end{tabular}

(Sumber: Hasil analisis data SPSS)

\section{Pembahasan}

\section{a. Pemanfaatan Perpustakaan Oleh Peserta Didik di SMK Pratidina Makassar}

Pemanfaatan perpustakaan di SMK Pratidina Makassar yang peneliti dapatkan melalui angket dengan pengembangan 2 indikator yakni persepsi dan motivasi pemanfaatan perpustakaan. Hasil penghitungan jawaban angket dari responden menunjukkan jawaban sangat baik sebesar 59,4\%, jawaban baik sebesar 27,5\%, jawaban ragu-ragu sebesar $11,7 \%$, jawaban kurang baik sebesar $1,4 \%$.

Perpustakaan sekolah berfungsi sebagai sarana yang menyediakan bahan-bahan pustaka yang mengandung unsur hiburan yang sehat dan bermanfaat. Buku-buku yang ada di perpustakaan dapat dimanfaatkan sebaik-baiknya oleh peserta didik sebab perpustakaan merupakan sarana penunjang proses pembelajaran di sekolah. Tujuan diselengarakannya perpustakaan sekolah ialah untuk memenuhi kebutuhan informasi bagi masyarakat dilingkungan sekolah yang bersangkutan, khusunya para pendidik dan peserta didik sebagai media dan sarana untuk menunjang kegiatan proses pembelajaran di tingkat sekolah. Hal ini sesuai dengan pendapat Pawit M. Yusuf, tujuan diselengarakannya perpustakaan sekolah ialah untuk memenuhi kebutuhan informasi bagi masyarakat dilingkungan sekolah yang bersangkutan, khusunya para pendidik dan peserta didik sebagai media dan sarana untuk menunjang kegiatan proses pembelajaran di tingkat sekolah. Secara singkat dapat dikatakan bahwa perpustakaan sekolah bertujuan untuk mempertinggi kualitas dan kemampuan keilmuan para peserta didik dalam proses pembelajaran serta membantu memperluas cakrawala berpikir para peserta didik dalam lingkungan sekolah tersebut. Perpustakaan SMK Pratidina Makassar menyediakan bahan bacaan bagi peserta didik sesuai dengan disiplin ilmu keperawatan dan umum sebagai sarana penunjang pembelajaran yang dapat dimanfaatkan di sekolah dan dapat dipinjamkan.

Sejak diberlakukannya kurikulum 2013 oleh Kemendikbud, peran perpustakaan sebagai pusat belajar mandiri menjadi semakin sentral. Hal itu terjadi karena sistem kurikulum 2013 lebih mengedepankan keaktifan peserta didik dalam belajar secara mandiri. Olehnya itu, peserta didik semakin giat memanfaatkan perpustakaan sebagai salah satu upaya meningkatkan prestasi belajar mereka. Seluruh sarana pembelajaran tersimpan secara sistematis dan terstruktur di perpustakaan. Olehnya itu, peserta didik dapat mencari sendiri literatur yang dibutuhkan atau dapat meminta bantuan kepada staf 
perpustakaan dalam mendapatkan bahan pustaka yang mereka butuhkan maupun kebutuhan informasi.

Pemanfaatan perpustakaan yang maksimal dapat diwujudkan dengan meningkatkan kesadaran peserta didik akan pentingnya membaca, belajar madiri dalam meningkatkan pengetahuan, peran guru dalam memotivasi peserta didik dengan memberikan tugas yang diwajibkan mencari literatur di perpustakaan serta peran sekolah dalam mengembangkan dan membina perpustakaan sekolah agar senatiasa diperbarui koleksinya, memperluas ruang belajar, meningkatkan fasilitas perpustakaan dengan mengikuti kemajuan teknologi informasi.

\section{b. Prestasi Belajar Peserta didik SMK Pratidina Makassar}

Hasil analisis menunjukkan bahwa untuk mengetahui gambaran prestasi belajar peserta didik SMK Pratidina Makassar melalui pengembangan indikator prestasi belajar dapat dilihat pada nilai yang diperoleh peserta didik dalam buku raport. Prestasi belajar merupakan perubahan tingkah laku yang dapat mencerminkan perubahan yang terjadi sebagai prestasi belajar peserta didik, baik yang berdimensi cipta, rasa maupun karsa.

Menurut S. Nasution prestasi belajar adalah suatu perubahan individu yang belajar, perubahan tidak hanya mengenai pengetahuan juga membentuk kecakapan, kebiasaan diri pribadi individu yang belajar. Peserta didik SMK Pratidina memanfaatkan perpustakaan sebagai sarana pembelajaran tambahan diluar jam pelajaran. Meraka belajar secara mandiri di perpustakaan untuk meningkatkan wawasan berpikir sebagai bahan referensi berdiskusi di kelas atau di luar kelas, secara formal maupun non-formal.

Alisuf Sabri mengemukakan bahwa, belajar adalah "Proses perubahan tingkah laku sebagai akibat pengalaman atau latihan". M. Dalyono, berpendapat belajar adalah "perubahan-perubahan lahir dan batin, tidak hanya perubahan-perubahan yang tidak dapat diamati, perubahan yang positif, yaitu perubahan yang menuju ke arah kemajuan atau ke arah perbaikan." Proses belajar yang dilakukan oleh peserta didik SMK Pratidina Makassar adalah konsep belajar sepanjang hayat. Secara tidak langsung, mereka telah membiasakan diri untuk belajar dan mencintai pembelajaran secara mandiri sehingga dimanapun mereka berada, sebagaimana pendapat Trianto "Proses belajar terjadi melalui banyak cara, baik disengaja maupun tidak disengaja dan berlangsung sepanjang waktu dan menuju pada suatu perubahan pada diri si pelajar. ${ }^{9}$ Peserta didik SMK Pratidina Makassar sudah terbiasa belajar secara mandiri dan memiliki rasa ingin tahu yang tinggi. Itulah konsep pembelajaran sepanjang hayat yang ditawarkan oleh perpustakaan. Dengan proses pembiasaan belajar mandiri, secara lambat laun hasil dari proses dan pengalaman belajar mandiri mereka akan berpengaruh pada tingkah laku dan perubahan ke arah yang lebih baik dan tentunya akan berpengaruh pada prestasi belajarnya.

Peran prestasi belajar seperti diuraikan di atas tidak hanya sebagai indikator keberhasilan peserta didik dan kualitas institusi semata, akan tetapi prestasi belajar juga berfungsi sebagai umpan balik bagi para guru dalam merancang dan melaksanakan pembelajaran serta melakukan tindak lanjut bagi peserta didik yang belum mencapai prestasi belajar yang baik. Prestasi belajar tersebut dapat menjadi acuan dalam mengembangkan sistem belajar yang lebih baik. Berhasil atau tidaknya peserta didik

\footnotetext{
${ }^{9}$ Trianto, Mendesain Model Pembelajaran Inovatif-Progresif: Konsep, Landasan, dan Implementasinya pada Kurikulum Tingkat Satuan Pembelajaran (KTSP), h. 16.
} 
dalam pembelajaran, dengan kata lain, memperoleh prestasi belajar yang baik maka sangat bergantung pada pembelajaran yang dilakukan oleh peserta didik. Pembelajaran yang berkualitas maka menghasilkan prestasi belajar yang baik pula.

\section{c. Pemanfaatan Perpustakaan dan pengaruhnya terhadap prestasi belajar peserta didik di SMK Pratidina Makassar}

Sebagaimana hasil dari penelitian ini, ditemukan bahwa pemanfaatan perpustakaan berpengaruh sebesar $67,7 \%$ yang artinya lebih dari setengah prestasi belajar peserta didik dipengaruhi oleh persepsi dan motivasi belajar mandiri mereka di perpustakaan, sebab perpustakaan menyimpan buku-buku penting yang dibutuhkan oleh peserta didik. Pengadaan jam khusus perpustakaan pada jadwal mata pelajaran di SMK Pratidina Makassar selama alokasi waktu 2 jam perhari setiap minggu berdampak baik peserta didik dan prestasi belajar mereka sebagaimana teori Hukum Jost.

Dari hasil penelitian, ditemukan sebesar 32,3\% prestasi belajar dipengaruhi oleh variabel lain sedangkan pengaruh pemanfaatan perpustakaan sebesar $67,7 \%$. Temuan tersebut menggambarkan adanya pengaruh yang cukup signifikan antara pemanfaatan perpustakaan dengan prestasi belajar. Dalam penelitian ini, peneliti berasumsi bahwa dengan besarnya pengaruh yang diberikan oleh perpustakaan sebesar 67,7\% disebabkan karena perpustakaan sebagai pusat belajar mandiri yang didalamnya menyimpan beragam informasi yang dibutuhkan oleh peserta didik. Buku-buku mata pelajaran, Karya Tulis Ilmiah, kamus, buku-buku keperawatan dan lain-lain semuanya tersimpan secara terstruktur di perpustakaan. Peserta didik diberikan kesempatan seluas-luasnya untuk belajar sesuai dengan keinginannya selama tidak membuat kegaduhan dalam ruang perpustakaan. Disediakan fasilitas dan sistem temu balik informasi yang akurat dan tenaga pustakawan yang selalu siap memberikan layanan informasi bagi peserta didik. Temuan tentang pentingnya memanfaatkan perpustakaan dan pengaruhnya terhadap prestasi belajar ini mewakili secara umum bahwa persepsi dan motivasi peserta didik untuk meningkatkan minat baca dan belajar mandiri adalah hal yang begitu penting dalam meningkatkan wawasan berpikir dan prestasi belajar peserta didik.

\section{PENUTUP}

Hasil penelitian menunjukkan tingkat pemanfaatan perpustakaan secara deskriptif dan menggambarkan jawaban responden terhadap angket pemanfaatan perpustakaan SMK Pratidina Makassar, jawaban sangat baik sebesar 59,3\%, menyatakan baik sebesar 27,5\%, jawaban ragu-ragu sebesar $11,7 \%$, dan jawaban pernyataan kurang baik sebesar $1,4 \%$. Asumsi dari data tersebut menyatakan bahwa pemanfaatan perpustakaan SMK Pratidina Makassar yang ditunjukkan melalui indikator-indikator yang terdapat pada angket berada pada kategori sangat baik dalam memanfaatkan perpustakaan. Kategori sangat baik dibuktikan dengan jawaban responden yang menjawab sangat baik dan baik jauh lebih banyak jika dibandingkan dengan yang menjawab kurang baik. Data tersebut menggambarkan secara umum peserta didik SMK Pratidina Makassar secara rata-rata memiliki persepsi dan motivasi yang sangat baik terhadap perpustakaan dan selalu memanfaatkan perpustakaan dalam pembelajaran setiap hari di sekolah demi mendongkrak peningkatan prestasi belajar mereka.

Merupakan nilai raport peserta didik kelas XII A, XII B, XII C dan XII D yang peneliti ambil pada tata usaha SMK Pratidina Makassar dengan melihat tingkat pemanfaatan perpustakaan yang ada pada data administrasi perpustakaan SMK 
Pratidina Makassar kemudian peneliti cocokkan dengan tingkat prestasi belajar mereka. Berdasarkan observasi dan penelusuran dokumentasi pada perpustakaan SMK Pratidina Makassar, peneliti menemukan bahwa peserta didik yang rajin memanfaatkan perpustakaan pada setiap kesempatan memiliki prestasi yang gemilang jika dibandingkan dengan peserta didik yang kurang memanfaatkan perpustakaan atau hanya belajar di perpustakaan pada saat jam pustaka. Peserta didik yang tertera namanya di atas adalah peserta didik yang rajin masuk ke perpustakaan, baik pada waktu jam pustaka maupun pada saat jam istirahat dan pada saat jam kosong. Mereka rajin meminjam buku-buku perpustakaan berdasarkan pada data peminjaman yang ada pada perpustakaan.

Nilai prestasi belajar peserta didik melalui penghitungan rumus regresi linier sederhana sebesar 29,138 tersebut menunjukkan bahwa semakin tinggi frekuensi pemanfaatan perpustakaan maka semakin tinggi peningkatan prestasi belajar peserta didik, hasil tersebut dapat dilihat pada tabel IV.15 analisis regresi linier sederhana menunjukkan bahwa bahwa setiap pemanfaatan perpustakaan akan meningkatkan prestasi belajar peserta didik SMK Pratidina Makassar sebesar 0,703. Untuk mengetahui besarnya pengaruh pemanfaatan perpustakaan terhadap prestasi belajar, digunakan angka $\mathrm{R}$ square (angka korelasi yang dikuadratkan). Angka $\mathrm{R}$ square disebut juga Koefisien Diterminasi (KD) besarnya angka Koefisien Diterminasi dalam penghitungan di atas ialah sebesar 0,677 atau sama dengan 67,7\%. Angka tersebut mempunyai arti bahwa besarnya pengaruh pemanfaatan perpustakaan terhadap prestasi belajar sebesar 67,7\% sedangkan sisanya, yaitu 32,3\% (100\%-67,7\%) di pengaruhi oleh variabel lain. Berdasarkan tabel interpretasi tingkat pengaruh yakni berada pada kategori cukup tinggi. Pengujian dilakukan dengan menggunakan angka signifikansi atau sig pada tabel IV.18 dengan ketentuan sebagai berikut: Jika angka signifikansi penelitian < 0,05; maka $\mathrm{H} 0$ ditolak dan $\mathrm{H} 1$ diterima. Jika angka signifikansi penelitian > 0,05; maka H0 diterima dan $\mathrm{H} 1$ ditolak. Berdasarkan hasil penghitungan diperoleh angka signifikansi sebesar 0,00. Angka 0,00 > 0,05. Oleh karena itu, H0 ditolak dan H1 diterima. Artinya ada hubungan linier antara variabel pemanfaatan perpustakaan dengan prestasi belajar. Oleh karena terdapat hubungan linier antara kedua variabel maka frekuensi pemanfaatan perpustakaan memengaruhi prestasi belajar peserta didik di SMK Pratidina Makassar. 


\section{DAFTAR PUSTAKA}

Arikunto, Suharsimi, Prosedur Penelitian: Suatu Pendekatan Praktik (Ed. Rev., Cet. I

Bafadal, Ibrahim. Pengelolaan Perpustakaan Sekolah. Jakarta: Bumi Aksara. h. 20

Departemen Pendidikan Nasional, Kamus Besar Bahasa Indonesia: Cetakan Keempat. Jakarta: Balai Pustaka.

Mulyasa, Implemntasi Kurikulum 2004 Panduan Pembelajaran KBK, Cet IV; Bandung: PT Remaja Rosdakarya, 2006), h. 195.

Syah, Muhibbin, Pisikologi Pendidikan dengan Pendekataan Baru, Cet 15; Bandung: PT Remaja Rosdakarya, 2010.

Trianto, Mendesain Model Pembelajaran Inovatif-Progresif: Konsep, Landasan, dan Implementasinya pada Kurikulum Tingkat Satuan Pembelajaran (KTSP)

Undang-Undang Republik Indonesia nomor, 43 tahun 2007 tentang Perpustakaan, Jakarta:Perpustakaan Nasional. 